\title{
Macroscopic gonadal deviations and intersex in developing whitefish Coregonus lavaretus
}

\author{
Daniel Bernet*, Thomas Wahli, Sibylle Kipfer, Helmut Segner
}

Centre for Fish and Wildlife Health, University of Bern, Laenggass-Strasse 122, PO Box 8466, 3001 Bern, Switzerland

\begin{abstract}
In Lake Thun, Switzerland, a significant number of whitefish Coregonus lavaretus were found to exhibit abnormal gonadal morphology. To determine the time at which the morphological deviations from a normal gonadal arrangement develop, we conducted experiments designed to: (1) examine whether the morphologic gonadal variations develop during or after gonadal differentiation, and (2) characterise the entire ontogenetic gonadal development in whitefish from hatching until maturity. For these experiments, whitefish were reared under controlled conditions with distinct water sources and temperature regimes (Lake Thun water: 4 to $22^{\circ} \mathrm{C}_{i}$ spring water: 8 to $9^{\circ} \mathrm{C}$ ). Gonadal development in the spring water group was clearly delayed with respect to age, but similar to the Lake Thun water group with respect to degree-days in Celsius $\left({ }^{\circ} \mathrm{D}\right)$. Undifferentiated gonads were first seen at $65 \mathrm{~d}$ post-hatch and $491^{\circ} \mathrm{D}$. Ovarian differentiation (starting from 1734 to $1820^{\circ} \mathrm{D}$ ) preceded testicular differentiation (starting from 1989 to $3673^{\circ} \mathrm{D}$ ). The first fish with mature germ cells were recognised at 8163 to $8356^{\circ} \mathrm{D}$. Morphological gonadal deviations became evident during gonadal differentiation. Constrictions and asymmetries developed for the first time in the first $(0+)$ or second (1+) year-of-life, at a body length of 13 to $18 \mathrm{~cm}$. Aplasia and compartmentation were recorded in the third (2+) year-of-life at a body length of 16 to $18 \mathrm{~cm}$. Intersex fish occurred at a frequency of 8 to $9 \%$ during gonadal sex differentiation. Because no evidence for the presence of exogenic endocrine active substances was revealed, we suppose that there is a naturally increased mosaic intersex condition in whitefish during the ontogenetic gonadal differentiation process.
\end{abstract}

KEY WORDS: Whitefish · Coregonid · Gonad · Ontogeny · Sex differentiation · Intersex · Reproduction • Gonad morphology

Resale or republication not permitted without written consent of the publisher

\section{INTRODUCTION}

Several cases of fish populations with altered gonadal morphology have been recorded in recent years (Ruby \& Cairns 1983, Demska-Zakes \& Mamcarz 1996, Wiklund et al. 1996, Fitzsimons \& Cairns 2000, Simpson et al. 2000, Kinnison et al. 2000, Mikaelian et al. 2002). From Lake Thun, Switzerland, fish populations are reported to develop gonads deviating from an ideal, normal gonad morphology (Bernet et al. 2004). Not being able-at that time-to interpret correctly the observed variations in gonadal morphologies in respect of their normality/abnormality, we used the term 'deviated gonads' to describe the variations in gonadal morphology, explicitly avoiding attributes with pejorative connotations such as 'abnormal', 'deformed', 'malformed' and/or 'altered'. Whitefish Coregonus lavaretus from Lake Thun display a high frequency of macro- and microscopic deviations of gonadal morphology: (1) adhesions/fusions of the gonads, or parts thereof, to the peritoneal wall and the musculature; (2) asymmetry of the left and right gonad strands with respect to their volume (classed as asymmetrical when the difference in volumes is $>50 \%$ ); (3) atrophy and aplasia, when one or both gonad strands are undeveloped (atrophy) or totally absent (aplasia); (4) compartmentations, where the gonads are divided into several separated lobes connected with each other by the sperm duct (males) or the ovarian envelope (females); (5) constrictions, where the gonads are seg- 
mented into several lobes, but-in contrast to compartmentations - testicular or ovarian tissue is still present in the intersection parts and the lobes are not locally separated from each other; and (6) simultaneous hermaphroditism and intersex condition, where testicular and ovarian tissue occur in the same individual.

An extensive surveillance of whitefish populations in Lake Thun and 2 neighbouring lakes over several years provided epidemiological criteria to distinguish between normal and abnormal gonadal morphologies (Bittner et al. 2009). From the different types of gonadal deviations described above, only compartmentation, gonadal fusions to the peritoneal wall, intersex and aplasia were found to be characteristic of whitefish in Lake Thun. These 4 morphological traits were present at significantly higher frequencies in whitefish from Lake Thun than in whitefish from the neighbouring lakes. Thus, the authors assessed only these 4 morphologic gonadal variations as true gonadal deformations. In contrast, asymmetries and constrictions were frequent in coregonids of all 3 lakes and are therefore considered as part of the natural variation in gonadal morphology of whitefish.

The primary cause(s) of the morphological gonadal variations of Lake Thun whitefish are not yet understood. What is known is that the frequency of abnormal gonads is influenced by factors such as sex, age, spawning site and also by the different whitefish ecomorphs living sympatrically in Lake Thun (Bernet et al. 2004, Bittner et al. 2009). With respect to age, fish with deformed gonads were observed in all age classes from $\geq 2 \mathrm{yr}$, with prevalences increasing in older fish. Information on gonadal deviation in fish $<2$ yr of age is limited. Due to gill netting limitations in the lake, it is difficult to sample representative numbers of the younger age classes. Furthermore, we do not know when the different morphological gonadal deviations develop, if they appear concomitantly with gonad sexual differentiation or if they are imposed on the already differentiated gonad. This information is relevant to understand the aetiology of the gonadal aberrations. Therefore, the aim of the present study was to examine whether the morphological gonadal deviations of whitefish from Lake Thun are present in fish younger than 2 yr of age, and whether they develop parallel to sexual differentiation. As the gonadal ontogeny of whitefish has not been described to date, the first task of the present study was to document the ontogeny of sexual differentiation in whitefish. To this end, we reared whitefish from Lake Thun under controlled conditions and sampled them at regular intervals from hatching until sexual maturity at $3 \mathrm{yr}$ of age. Since developmental processes in fish are known to be strongly influenced by water temperature, we studied gonadal ontogeny of Lake Thun whitefish under 2 dif- ferent temperature regimes, i.e. Lake Thun water with seasonal variations and spring water at a constant 8 to $9^{\circ} \mathrm{C}$, in order to see whether the onset of deviations in gonadal morphology varies with the temperature profile.

\section{MATERIALS AND METHODS}

Fish maintenance. There are 4 whitefish Coregonus lavaretus ecomorphs living sympatrically in Lake Thun. Mature whitefish of the ecomorph with the local name 'Albock' were caught in Lake Thun in December 2002 in their spawning grounds by bottom gill nets. Eggs from approximately 50 females were stripped and pooled, and semen from approximately 30 males was added. The eggs were incubated in a Zuger jar supplied with water from Lake Thun. After hatching in February 2003, the larvae were kept in a circular, 2000 l fibreglass tank supplied with Lake Thun water (hereafter 'Lake Thun water group') and fed dry food (in the first months AgloNorse Nos. 1 and 2, EWOS AS; and thereafter Silvercup 500 to 503, Hokovit) supplemented with frozen zooplankton from Lake Thun. Fish were reared until the first individuals reached maturity in July 2005. Water temperature followed seasonal variation with minimum values of $4^{\circ} \mathrm{C}$ in February 2005 and a maximum of $22^{\circ} \mathrm{C}$ in August 2003 (Fig. 1).

We ran a second rearing experiment to examine the extent to which gonadal development varied with rearing conditions. Eggs of 60 female whitefish (Albock form) collected from Lake Thun in December 2004 were fertilised according to a North Carolina II design (Lynch \& Walsh 1998), i.e. the eggs of every female were subdivided into batches and fertilized blockwise. Within each block, on average 4 to 6 males fertilized individually the eggs of a similar number of females, according to a fully factorial breeding design.

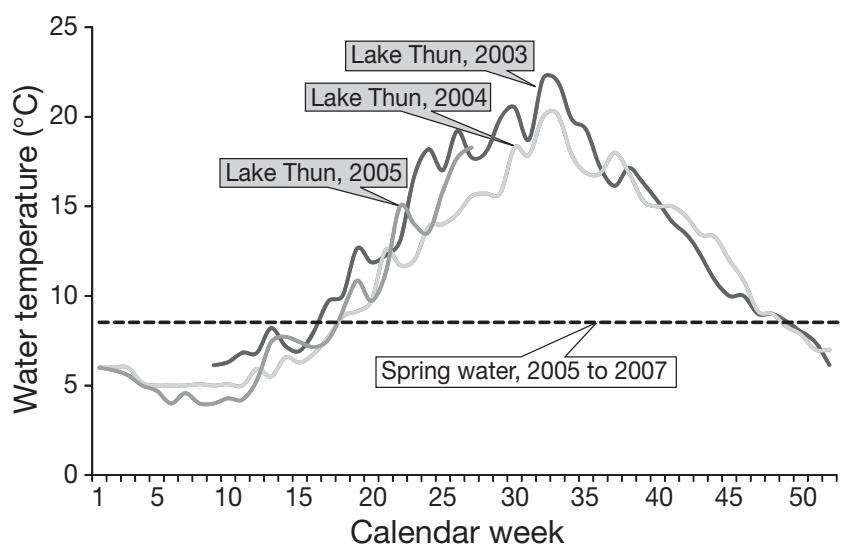

Fig. 1. Water temperature regime of Lake Thun during the experimental period 2003 to 2005 and of the spring water during the experimental period 2005 to 2007 
Thus, within each block, all possible parental combinations were represented. The fertilised eggs were incubated, and hatched fish were reared at a governmental fish farm near Lake Thun. The facility is supplied with spring water emerging at the bottom of a mountain slope at a constant temperature of 8 to $9^{\circ} \mathrm{C}$ (hereafter 'spring water group'). After hatching, the larvae were transferred into a circular, 20001 fibreglass tank supplied with spring water and fed exclusively dry food (same regimen as Lake Thun water group). Fish were maintained until October 2007.

Fish were reared at both locations under natural photoperiodicity, not differing between the 2 sites, situated $8 \mathrm{~km}$ away from each other. All fish were reared in flow-through tanks with a water flow rate of 10 to $151 \mathrm{~min}^{-1}$. Oxygen concentrations did not fall below $7.5 \mathrm{mg} \mathrm{l}^{-1}$.

In ectotherms, physiological processes that determine growth and development are directly influenced by temperature (Atkinson 1994). Therefore, the rate of gonadal sex differentiation of fish varies with water temperature (e.g. Krol et al. 2003). Thus, numerical age (in days post-hatch [dph]) is not an appropriate unit to compare gonadal development between individuals reared at different water temperatures. For this reason, we describe gonadal development both in terms of numerical age and in terms of degree-days $\left({ }^{\circ} \mathrm{D}\right)$, a sum of the mean daily water temperatures in Celsius (Neuheimer \& Taggart 2007), to account for the temperature influence.

Sample collection. Fish from the Lake Thun water group were sampled weekly in the first 5 mo after hatching, and subsequently once a month during the following 5 mo. During the second and third year of life, fish were sampled regularly, 3 times a year.

Sampling of the spring water group began when the fish were $169 \mathrm{~d}$ old and were thought to have started ovarian differentiation. Samples were taken monthly until the completion of the first year, thereafter 5 times in the second and twice in the third year of life.

At every sampling, 15 to 20 fish were euthanized with an overdose of Finquel (Argent Chemical Laboratories). Fish up to a length of $7 \mathrm{~cm}$ were fixed in toto. Larger fish were first opened ventrally before fixation in $4 \%$ buffered formalin. As soon as the gonads reached an adequate size in bigger fish (about $>12 \mathrm{~cm}$ body length), they were excised and preserved in buffered formalin.

Fixed fish $\leq 7 \mathrm{~cm}$ were cut longitudinally and embedded in paraffin. Gonads from larger in toto fixed fish were removed before embedding. All excised gonads were morphologically assessed according to Bernet et al. (2004), i.e. for each individual the presence or absence of the following morphological states was recorded: constriction, asymmetry, atrophy/aplasia, compartmentation, adhesion/fusion and intersex. From all paraffin blocks, sections of 3 to $5 \mu$ m were mounted on slides, stained with Mayer's haematoxylin and eosin and examined by light microscopy. The histological assessment of the germ cells during the gonadal differentiation followed the descriptions of Patino \& Redding (2000), Nolan et al. (2001) and van Aerle et al. (2004). Fish were assessed as functionally mature as soon as ripe germ cells, i.e. ovulated oocytes or milt, were released.

Furthermore, gonad histology was assessed in 275 wild whitefish (age: mean $2.9 \mathrm{yr}$, min. 1 yr, max. 7 yr) from Lake Thun to reveal the prevalence of mosaic type intersex gonads in the free-living whitefish population from Lake Thun. Twenty-five fish were collected every month from hauls of commercial fishermen, except in November when fishing was suspended due to the spawning season. Gonads from these fish were excised and fixed in $4 \%$ buffered formalin. The preparation of histological slides followed the same process as described above.

Measurement of vitellogenin mRNA. Hepatic vitellogenin (VTG) mRNA was measured to assess exposure of the reared fish to estrogens and estrogen mimics. Elevated VTG levels in males indicate the presence of these substances in the environment of the fish. Relative quantification of the VTG mRNA gene expression was performed by means of a 2-step realtime RT-PCR, described in detail in Kipfer et al. (2009). In brief, total RNA was extracted from liver tissue using Trizol Reagent (Invitrogen), resuspended in RNA storage solution (Invitrogen) and treated with DNase (Ambion). Concentration of total mRNA was measured using a NanoDrop ND-1000 UV-vis spectrophotometer (NanoDrop Technologies). Subsequently, mRNA was transcribed into cDNA in a thermocycler (PTC-200 DNA Engine, MJ Research, BioConcept). Primers for Coregonus lavaretus for conventional RT-PCR were established using VTG mRNA sequences from Oncorhynchus mykiss, Danio rerio, Cyprinus carpio and Fundulus heteroclitus. RT-PCR amplification of the target gene was performed using a 1-step RT-PCR kit (Quiagen) and then checked on a subsequently sequenced agarose gel. Based on the partial VTG sequence, a forward (5'-ATC AAG AAG ACA CAG AAC GTC TAT GAG-3') and reverse (5'-CTG ATC ACA TAG TGG GTC TTG CA-3') primer and 1 internal fluorescent probe (5'-CCC TGA GCT CCA GCC TCC TGC A-3') were designed using primer express software (PE Biosystems). TaqMan real-time RT-PCRs were performed to determine the threshold cycle $\left(\mathrm{C}_{\mathrm{T}}\right)$ values of target and reference genes, using a 7300 Real-Time PCR System in conjugation with 7300 SDS software (Applied Biosystems). As a reference, mRNA of the 18s gene was measured using a TaqMan Riboso- 
mal RNA Control Reagents kit (Applied Biosystems). Transcript abundance of VTG was normalized to the abundance of $18 \mathrm{~s}$ and reported as number of VTG copies $1000^{-1}$ copies of $18 \mathrm{~s}$ according to Pfaffl (2001) and Garcia-Reyero et al. (2004).

Statistical analysis. Differences in intersex frequencies between groups were analyzed using Fisher's exact test. Group differences in hepatic VTG mRNA concentrations were tested with the non-parametric Kruskal-Wallis Z-test. All statistical analyses were performed using NCSS 2001 (Number Cruncher Statistical Systems). A p-value $\leq 0.05$ was considered significant.

\section{RESULTS}

\section{Ontogenetic gonadal development}

The time course of gonadal development and sexual differentiation varied considerably between individuals. For instance, at an age of $513 \mathrm{dph}$ or $6000^{\circ} \mathrm{D}$, most testes of males from the Lake Thun water group displayed the full range of sperm cell stages (from spermatogonia to mature sperm) and some males showed delayed development with testes containing only spermatogonia. In addition, variation of germ cell maturation occurred within the gonad tissue of individual fish. For instance, while most oocytes within an ovary were at the Balbiani body stage, a few oocytes had progressed to the cortical alveolus stage. To standardise the intra- and interindividual variability in germ cell maturation status, we used the most advanced stages of germ cell development to classify the ontogenetic status of sex differentiation in a particular individual.

\section{Undifferentiated gonad}

Gonads of whitefish are paired cords situated bilaterally to the swim bladder on either side of the dorsal mesentery, extending along the full length of the peritoneal cavity and terminating at the genital pore which is associated with the urogenital papilla. Primordial gonads were observed for the first time in fish at an age of $65 \mathrm{dph}$ and $491^{\circ} \mathrm{D}$, corresponding to a body length of $2 \mathrm{~cm}$ (Fig. 2). These undifferentiated gonads contained primordial germ cells (PGCs) which measured about $8 \mu \mathrm{m}$ in diameter and were characterised by a large, round and basophilic nucleus surrounded by clear cytoplasm. Often there was a small space between the PGCs and the surrounding somatic cells. The transition to ovaries or testes was indicated by the development of oogonia and spermatogonia, respectively. Histologically, oogonia and spermatogonia at this early stage were almost identical and difficult to distinguish from PGCs. Compared with PGCs, the putative oogonia and spermatogonia were slightly larger $(\sim 10 \mu \mathrm{m}$ in diameter), had a reduced nucleus-cytoplasm ratio and the nucleus showed heterochromatous structures.

\section{Ovarian differentiation}

Ovarian differentiation preceded testicular differentiation, starting in the Lake Thun water group at $147 \mathrm{dph}$ or $1820^{\circ} \mathrm{D}$ and in the spring water group at $202 \mathrm{dph}$ or $1734^{\circ} \mathrm{D}$, when fish measured on average $3.5 \mathrm{~cm}$ (spring water group: $5.5 \mathrm{~cm}$ ) in length (Fig. 2). The early ovary was identifiable by the presence of pre-meiotic oocytes in the leptotene stage (often referred to as the 'bouquet stage', characterized by finger-like structures in the nucleus, and $\sim 7 \mu \mathrm{m}$ in diameter) and the zygotene stage (also 'chromatin-nucleolar stage', recognized by a single large basophilic nucleolus in the nucleus, and a slightly larger size, $\sim 30 \mu \mathrm{m}$ in diameter). These germ cell stages were observed during a short time period in the Lake Thun water group (for $53 \mathrm{~d}$, from 147 to $200 \mathrm{dph}$, or approx. $1000^{\circ} \mathrm{D}$ ), but over a longer period (for $233 \mathrm{~d}$, from 202 to $435 \mathrm{dph}$, or approx. $2000^{\circ} \mathrm{D}$ ) in the spring water group with lower temperatures. They occurred at a time when fish experienced a significant boost in body growth: from 3.5 to $10 \mathrm{~cm}$ in the Lake Thun water group and from 5.5 to $8.5 \mathrm{~cm}$ in the spring water group. Parallel to the presence of germ cells at the bouquet and chromatin-nucleolar stage, the ovaries started to form typical lamellar structures.

The lamellar structures, together with the premeiotic germ cell stages, made the transition from the undifferentiated gonad into ovarian tissue clearly evident. The next stage in oocyte development was the peri-nucleolar stage (diplotene phase), which was

Fig. 2. Coregonus lavaretus. Occurrence of various germ cell types and reaching of functional maturity after differentiation (dotted black line) into ovaries (F) and testes (M) of fish from the Lake Thun (black bars) and spring (grey bars) water groups in relation to (a) degree-days post-hatch, (b) age (days post-hatch and (c) body length. Data are shown for the most advanced males and females within the sample. Intersex specimens were not considered for this figure because these individuals often showed advanced stages of germ cell differentiation compared with pure males and females (see Fig. 4), which would have interfered with the characterisation of gonadal differentiation of distinct males and females. Numbers near the bars represent the first (left) and/or last (right) occurrence of the particular cell type stage as exact values. Dashed grey bars indicate that the first sampling took place after development of undifferentiated gonads but shortly before onset of female differentiation 

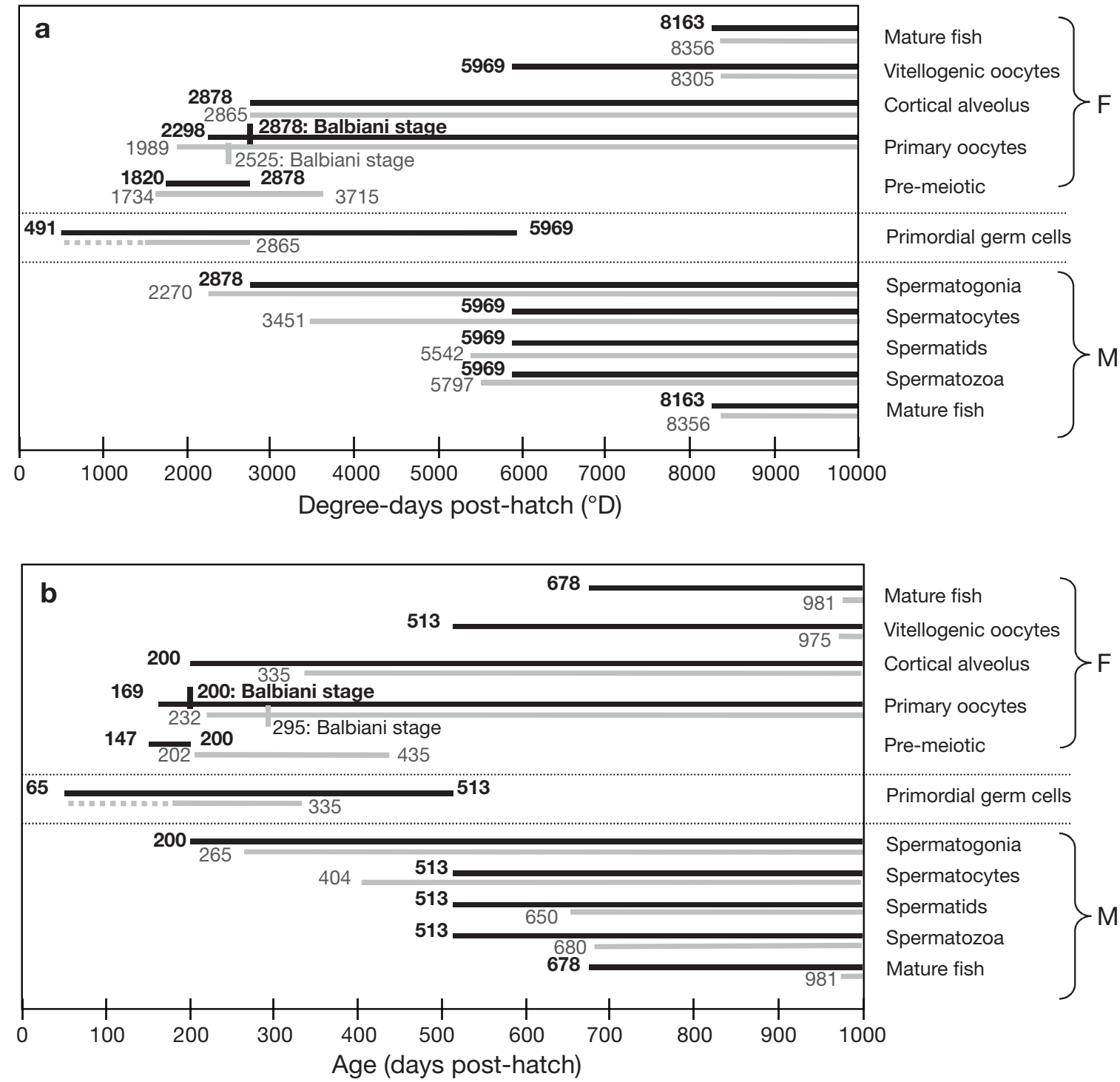

$\left.\begin{array}{l}\text { Mature fish } \\ \text { Vitellogenic oocytes } \\ \text { Cortical alveolus } \\ \text { Primary oocytes } \\ \text { Pre-meiotic }\end{array}\right\} \mathrm{F}$

Primordial germ cells

Spermatogonia

Spermatocytes

Spermatids

Spermatozoa

Mature fish

c

19

$16.5^{\mathbf{1 7 . 5}}$

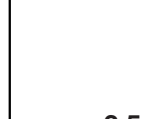

10: Balbiani stage
2

3.5
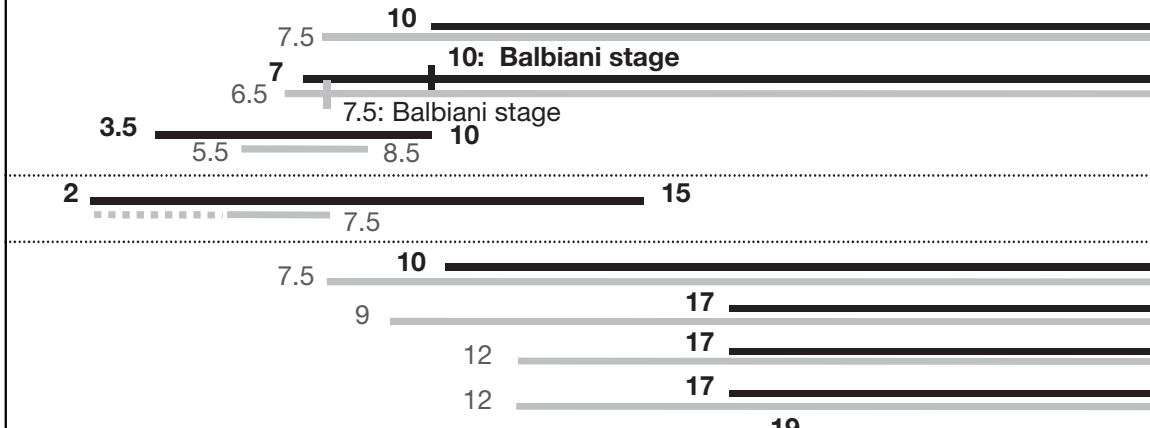

15

19

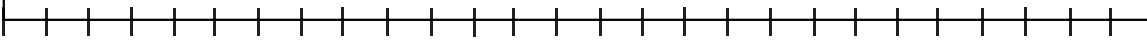

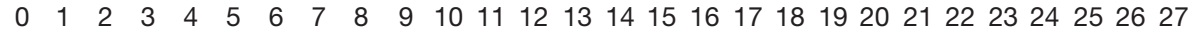

Body length (cm)
Mature fish

Vitellogenic oocytes

Cortical alveolus

Primary oocytes

Pre-meiotic

Primordial germ cells

Spermatogonia

Spermatocytes

Spermatids

Spermatozoa

Mature fish 
observed from $169 \mathrm{dph}$ or $2298^{\circ} \mathrm{D}$ onwards, when fish were $7 \mathrm{~cm}$ in length (spring water group: $232 \mathrm{dph}$, $\left.1989^{\circ} \mathrm{D}, 6.5 \mathrm{~cm}\right)$. Peri-nucleolar stage germ cells are characterized by the presence of nucleoli at the periphery of the nucleus and an increased size compared with the earlier stages (up to $60 \mu \mathrm{m}$ in diameter). Shortly after the peri-nucleolar stage, at $200 \mathrm{dph}$ and $2878^{\circ} \mathrm{D}$, a further stage of primary oocytes occurred, represented by the Balbiani body stage (spring water group: $295 \mathrm{dph}, 2525^{\circ} \mathrm{D}, 7.5 \mathrm{~cm}$ ); this cell stage is characterized by a further increased cell size (up to $80 \mu \mathrm{m}$ ). At $200 \mathrm{dph}$ and $2878^{\circ} \mathrm{D}$, the first oocytes of the cortical alveolus stage appeared, measuring $90 \mu \mathrm{m}$ in diameter (spring water group: $335 \mathrm{dph}, 2865^{\circ} \mathrm{D}, 7.5 \mathrm{~cm}$ ). From that time onwards, the development of the ovary came into a resting phase of almost $1 \mathrm{yr}$ (313 d) in the Lake Thun water group and almost 2 yr (640 d) in the spring water group. The only change in this period was an increase of the cortical alveolus oocytes in size up to $330 \mu \mathrm{m}$. The first vitellogenic oocytes were noticed at $513 \mathrm{dph}$ and $5969^{\circ} \mathrm{D}$, when fish measured at least $17.5 \mathrm{~cm}$ (spring water group: $975 \mathrm{dph}, 8305^{\circ} \mathrm{D}, 16.5 \mathrm{~cm}$ ). In the Lake Thun water group, the first mature and ovulated oocytes appeared in ovaries otherwise dominated by oocytes of the cortical alveolus stage, shortly before the completion of the second year at $678 \mathrm{dph}$ and $8163^{\circ} \mathrm{D}$ when fish measured $18 \mathrm{~cm}$. In the spring water group, this stage occurred almost $1 \mathrm{yr}$ later at $981 \mathrm{dph}$ or $8356^{\circ} \mathrm{D}$, when fish measured $19 \mathrm{~cm}$. The formation of an ovarian cavity was not recognised in any fish.

\section{Testicular differentiation}

The earliest identification of the onset of testicular differentiation in whitefish from the Lake Thun water group was possible at $259 \mathrm{dph}, 3673^{\circ} \mathrm{D}$ and at $11.5 \mathrm{~cm}$, with the formation of lobules in the testes (spring water group: $232 \mathrm{dph}, 1989^{\circ} \mathrm{D}, 6.5 \mathrm{~cm}$ ). In younger fish, no morphological features were present to enable us to distinguish between testes and ovaries according to Strüssmann \& Nakamura (2002). For instance: (1) spermatogonia were difficult to differentiate from PGCs; (2) somatic cells of the presumptive testis did not seem to be arranged differently than in the presumptive ovary as described in other fish species (Patino \& Redding 2000, van Aerle et al. 2004); (3) spermatogonia and oogonia were not histologically discernable; and (4) whitefish females did not develop an ovarian cavity. However, at around $200 \mathrm{dph}$ or $2878^{\circ} \mathrm{D}$ and at a fish length of $10 \mathrm{~cm}$, it could be assumed that those fish showing undifferentiated gonads represented male fish, because ovarian differentiation had started $53 \mathrm{~d}$ before and females were clearly identifiable at that time.
Spermatogonia were first unequivocally identifiable when they entered meiosis, which was at $513 \mathrm{dph}$ $\left(5969^{\circ} \mathrm{D}\right)$ in the Lake Thun water group, when fish measured more than $15 \mathrm{~cm}$ in body length (spring water group: $404 \mathrm{dph}, 3451^{\circ} \mathrm{D}, 9 \mathrm{~cm}$ ). From that time onwards, all germ cell stages up to spermatozoa developed within a short time (Fig. 2). Compared with ovarian differentiation, testicular differentiation was delayed (Lake Thun water group: $112 \mathrm{~d}$ or $1058^{\circ} \mathrm{D}$; spring water group: $30 \mathrm{~d}$ or $255^{\circ} \mathrm{D}$ ), but, once started, proved to be fast, continuous and did not show resting phases as seen in females between the cortical alveolus stage and the appearance of vitellogenic oocytes in ovaries. The first male with ripe milt was recognised at the same time as the first female with ripe ovulated ova, at $678 \mathrm{dph}$ and $8163^{\circ} \mathrm{D}$, measuring $19 \mathrm{~cm}$ in the Lake Thun water group (spring water group: $981 \mathrm{dph}$, $\left.8356^{\circ} \mathrm{D}, 15 \mathrm{~cm}\right)$.

\section{Morphologic gonadal deviations from normal development}

Constricted and asymmetric gonads (Fig. 3) were found early in the ontogenetic gonadal development of fish in our experiment. Constrictions occurred for the

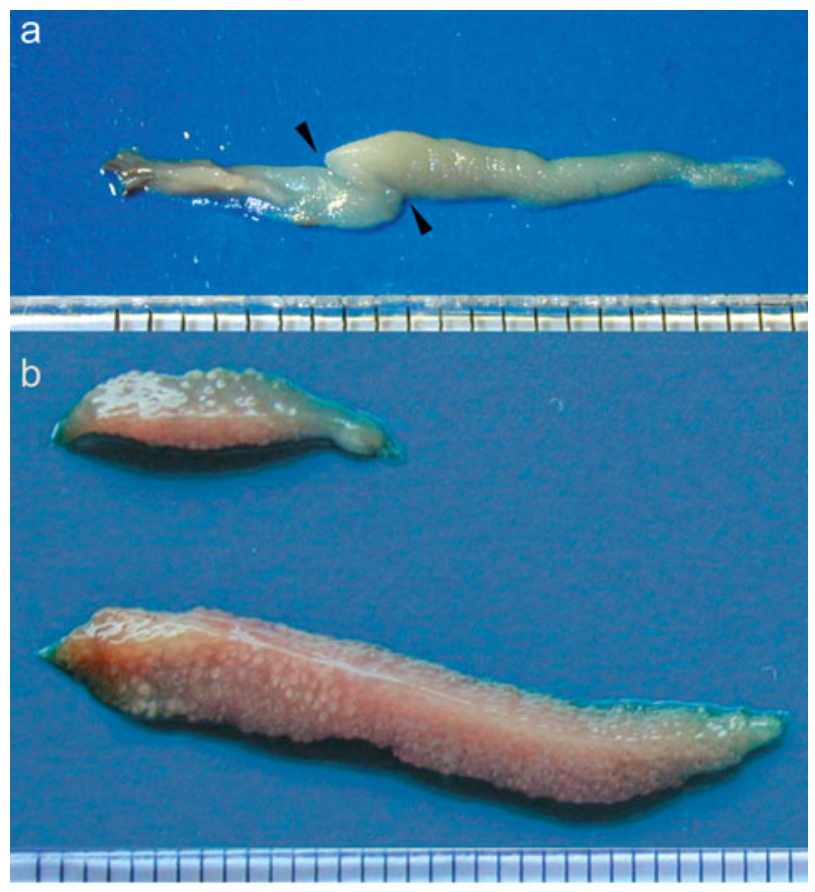

Fig. 3. Coregonus lavaretus. Two morphological deviations from normal gonadal development. (a) Constrictions (arrowheads) in the right testis of a fish from the Lake Thun water group at $291 \mathrm{dph}, 3949^{\circ} \mathrm{D}$ and $12.5 \mathrm{~cm}$ body length. (b) Asymmetrical ovaries of a female from the Lake Thun water group at $508 \mathrm{dph}, 5900^{\circ} \mathrm{D}$ and $15 \mathrm{~cm}$ body length. The marks on the scale represent $\mathrm{mm}$ 
first time at $291 \mathrm{dph}$ and $3949^{\circ} \mathrm{D}$, at a body length of $12.5 \mathrm{~cm}$ in the Lake Thun water group (spring water group: $650 \mathrm{dph}, 5542^{\circ} \mathrm{D}, 18 \mathrm{~cm}$ ). Asymmetry was first seen at $508 \mathrm{dph}$ and $5900^{\circ} \mathrm{D}$, at a length of $15 \mathrm{~cm}$ in the Lake Thun water group (spring water group: $981 \mathrm{dph}$, $\left.8356^{\circ} \mathrm{D}, 17.3 \mathrm{~cm}\right)$. Constrictions were present in 4 and $11 \%$ of fish from the Lake Thun and spring water groups, respectively. Asymmetrical gonads appeared in $0.6 \%$ of the fish from the Lake Thun water group and $0.9 \%$ of those from the spring water group.

Atrophy/aplasia and compartmentations were rarely observed $(0.9 \%)$ in our rearing experiment, and occurred only in the spring water group at an advanced stage of gonadal development $\left(>975 \mathrm{dph},>8305^{\circ} \mathrm{D}\right.$, $>15.5 \mathrm{~cm}$ ). Fusion of gonads with the peritoneal wall was never observed in the 2 experimental groups.

Histologically, a total of 34 mosaic intersex fish were identified in our experimental groups (Table 1). Intersex fish occurred with comparable frequencies in the Lake Thun $(8.0 \%)$ and spring water $(9.4 \%)$ groups (Fisher's exact test; $\mathrm{p}=0.72$ ). Conversely, intersex gonads in whitefish from both treatments were significantly more frequent than mosaic intersex gonads in adult wild fish from Lake Thun, where 3 of 275 fish showed testicular oocytes $(1.1 \%, \mathrm{p}<0.0003)$.

Thirty-one of 34 intersex fish displayed exclusively 'mosaic intersex gonad type' (Kinnison et al. 2000), also termed the 'multifocal distribution intersex type' (Nolan et al. 2001) characteristics. In mosaic intersex fish, ooyctes are scattered in testicular tissue or spermatogenic cells develop in ovarian tissue (Fig. 4). Three individuals displayed the 'lobular intersex gonad type' (Kinnison et al. 2000) or 'focal distribution intersex type' attributes (Nolan et al. 2001), characterised by confined sections of ovarian and testicular tissue along a gonad strand, often separated by undifferentiated connective tissue (Fig. 4d).

Intersex fish were observed for the first time at or shortly after the onset of the ovarian differentiation (Lake Thun water group: $169 \mathrm{dph}, 2298^{\circ} \mathrm{D}, 7 \mathrm{~cm}$; spring water group: $202 \mathrm{dph}, 1734^{\circ} \mathrm{D}, 4 \mathrm{~cm}$ ) (Fig. 5). These fish

Table 1. Coregonus lavaretus. Frequency of mosaic intersex fish from the 2 treatment groups, and in wild adult fish from Lake Thun. The number of fish analysed $\left(\mathrm{N}_{\text {fish }}\right)$, the number of intersex fish (N) and their relative frequency (\%), as well as the $95 \%$ confidence intervals based on a binomial distribution $\left(\mathrm{CI}_{95}\right)$, are given

\begin{tabular}{|lcccc|}
\hline & \multicolumn{4}{c|}{ Intersex } \\
\cline { 2 - 5 } Treatment groups & $\mathrm{N}_{\text {fish }}$ & $\mathrm{N}$ & $\%$ & $\mathrm{CI}_{95}$ \\
\hline Lake Thun water & 175 & 14 & 8.0 & $4.4-13.1$ \\
Spring water & 213 & 20 & 9.4 & $5.8-14.1$ \\
Wild, adult fish from & 275 & 3 & 1.1 & $0.2-3.2$ \\
$\quad$ Lake Thun & & & & \\
\hline
\end{tabular}

showed the typical lamellar structure of a distinct ovary (ovarian lamellae) with primary oocytes and single or rarely multiple interspersed spermatogenic cell nests (Fig. 4a). These nests usually consisted of spermatocytes and less frequently of spermatids. Interestingly, these spermatogenic cell stages appeared earlier in intersex fish than in pure males, where these cell stages were not present before $513 \mathrm{dph}, 5969^{\circ} \mathrm{D}$ and $17 \mathrm{~cm}$ in the Lake Thun water group (spring water group: $404 \mathrm{dph}, 3451^{\circ} \mathrm{D}, 9 \mathrm{~cm}$ ). This mosaic gonad type with predominantly ovarian character became less frequent during the further gonadal development of whitefish (Fig. 5). By contrast, the mosaic intersex type of predominantly testicular tissue with scattered primary oocytes became more prevalent (Fig. 4b). This type occurred for the first time shortly after the onset of testicular differentiation and could be recognized until the end of the experiment when fish were mature (Fig. 5).

\section{Vitellogenin}

VTG mRNA concentrations in males did not differ significantly between the Lake Thun and spring water groups (Kruskal-Wallis Z-test; $Z=1.04, \mathrm{~N}_{\text {Thun }}=8$, $\left.\mathrm{N}_{\text {Spring water }}=7, \mathrm{p}>0.05\right)$. VTG concentration in males ranged from 0.0005 to 3.24 copies VTG mRNA $1000^{-1}$ copies 18s-RNA (Fig. 6). VTG values in females were 3 (Lake Thun water group) to 5 orders (spring water group) of magnitude higher than in males. Females in the spring water group showed greater VTG values than those of the Lake Thun water group, reflecting the different developmental stages: Lake Thun females measured for VTG were in the early VTG stage, whereas ovaries of spring water females were in the late VTG stage shortly before maturity.

\section{DISCUSSION}

The present study presents the first histological description of the gonadal differentiation in a European whitefish species from hatching until maturity. At the same time, it provides an insight into the ontogenetic manifestation of the morphological gonadal deviations reported from Lake Thun coregonids.

Though there is detailed knowledge of gonadal development in species used in aquaculture (reviewed by Nakamura et al. 1998, Baroiller \& D'Cotta 2001, Piferrer 2001, Strüssmann et al. 2002) and species used for toxicological studies (medaka Oryzias latipes, Hamaguchi 1992, zebrafish Danio rerio, Maack \& Segner 2003, fathead minnow Pimephales promelas, van Aerle et al. 2004), information about differentiation in field species (neither regularly used in aqua- 

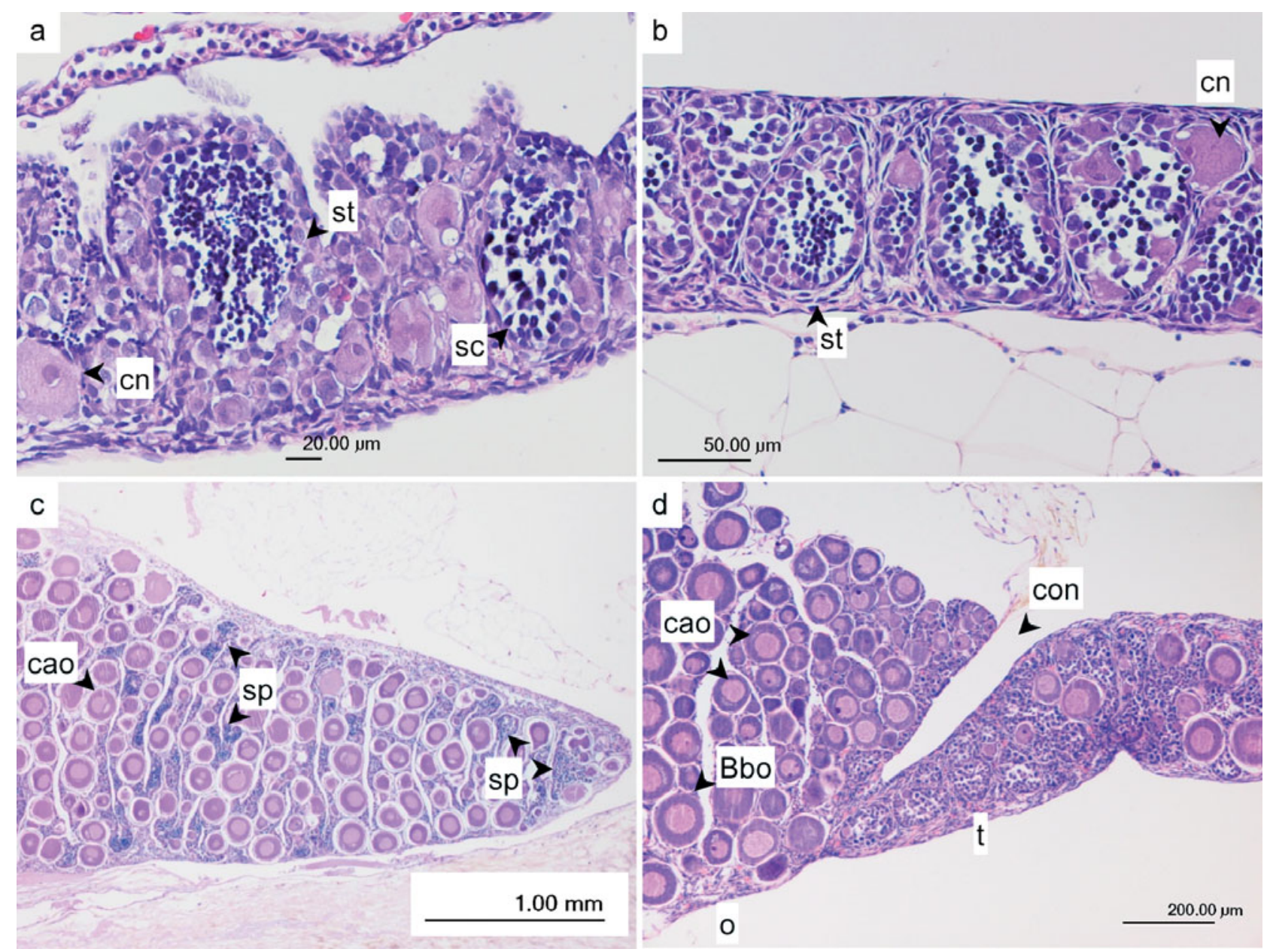

Fig. 4. Coregonus lavaretus. Transverse sections through mosaic intersex gonads. (a) Putative ovarian tissue showing the typical lamellar structure at an early developmental stage with oocytes at the chromatin-nucleolar stage (cn), oogonia arranged around the ovarian lamellae and the presence of 2 nests containing spermatocytes (sc) and spermatids (st). Spring water group fish, age: $295 \mathrm{dph}, 2525^{\circ} \mathrm{D}, 7.5 \mathrm{~cm}$. (b) Putative testicular tissue showing the lobular testis structure at an early developmental stage with spermatids in the lobules and a few oocytes at the chromatin-nucleolar stage arranged around the lobules. Spring water group fish, age: $232 \mathrm{dph}, 1989^{\circ} \mathrm{D}, 6 \mathrm{~cm}$. (c) Severe mosaic intersex in an ovarian tissue, showing the typical lamellar structure, presence of primary oocytes mostly at the cortical alveolus stage (cao) and nests containing spermatogenic cells (sp). Lake Thun water group fish, age: $200 \mathrm{dph}, 2878^{\circ} \mathrm{D}, 8 \mathrm{~cm}$. (d) Lobular and mosaic intersex, showing ovarian tissue (o) on the left, with the typical lamellar structure and oocytes at the Balbiani body stage (Bbo) and at the early cortical alveolus stage, well separated from the predominately testicular tissue (t) on the right by a constriction (con). Several oocytes of the Balbiani body stage are scattered within the testicular tissue, which is characterised by a lobular structure and the presence of presumptive spermatogonia. Spring water group fish, age: $680 \mathrm{dph}, 5797^{\circ} \mathrm{D}, 12 \mathrm{~cm}$

culture nor for experiments) is less frequent, and very rare for whitefish Coregonus spp. in particular (Dlugosz \& Demska-Zakes 1992, Bogdanova 2002, Krol et al. 2003). The results from the present study show that whitefish develop as gonochorists, with males differentiating later than females. Primordial, sexually indifferent gonads were first seen at $65 \mathrm{dph}$. This is slightly later than in rainbow trout Oncorhynchus mykiss (16 to 29 dph, van den Hurk \& Slof 1981) or coregonid species from other studies (C. peled: $39 \mathrm{dph}$, Krol et al. 2003; C. peled $\times$ C. nasus: $40 \mathrm{dph}$, Bogdanova 2002; C. lavaretus: 47 dph, Dlugosz \& Demska-Zakes 1992).
Water temperature was found to be an important modulating factor for gonadal development (i.e. Krol et al. 2003). In the Lake Thun water group, water temperature was 5.5 to $6.5^{\circ} \mathrm{C}$ in the first 2 mo after hatching, and thus significantly colder than in the experiments of Dlugosz \& Demska-Zakes $(1992)\left(>7^{\circ} \mathrm{C}\right)$ and Kroll et al. $(2003)\left(10^{\circ} \mathrm{C}\right)$. This explains the slight delay in the appearance of the primordial gonads in fish held in Lake Thun water compared with other coregonid studies. In the spring water group, with constant low water temperatures of 8 to $9^{\circ} \mathrm{C}$ throughout the year, gonadal development was clearly delayed and fish reached the 


\begin{tabular}{|lcc|}
\hline$\square$ Juvenile & $\begin{array}{l}\text { Mosaic intersex } \\
\text { (predominantly ovarian tissue) } \\
\square \text { Female } \\
\square \text { Male }\end{array}$ & $\begin{array}{c}\text { Mosaic intersex } \\
\text { (ovarian and testicular tissue equivalent) } \\
\text { (posaic intersex }\end{array}$ \\
\hline Lobular intersex \\
\hline
\end{tabular}

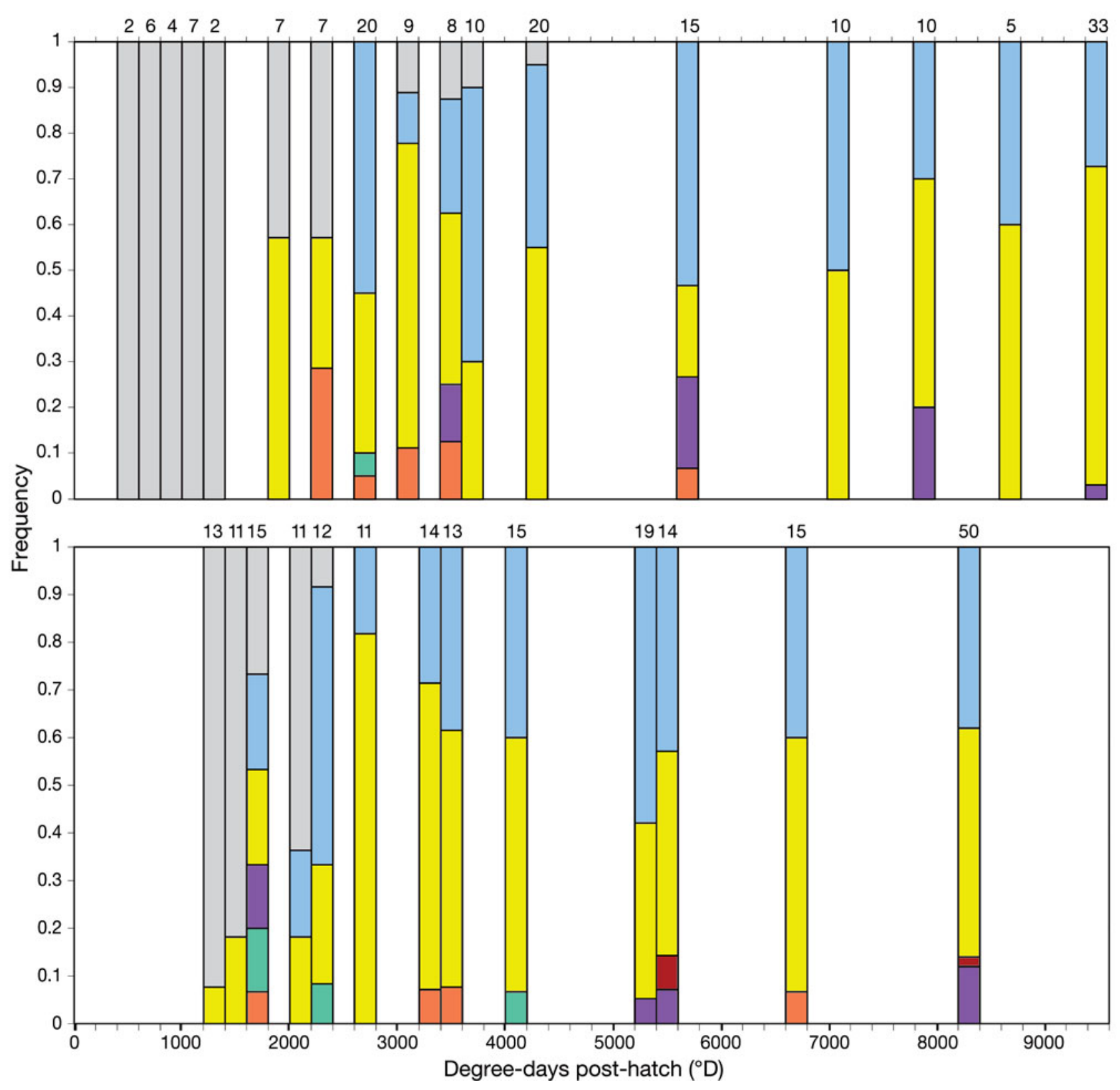

Fig. 5. Coregonus lavaretus. Proportion of the different phenotype sexes of whitefish from the 2 treatments (upper: Lake Thun water group; lower: spring water group) in relation to age, expressed as degree-days $\left({ }^{\circ} \mathrm{D}\right)$ post-hatch (grouped in classes of $\left.200^{\circ} \mathrm{D}\right)$. The numbers of fish of every sampling that were sexed histologically are indicated above each bar

different stages of gonadal development at an older age compared with fish from the Lake Thun water group. Differences in temporal development between these 2 groups blur, however, if the ontogenetic development is described by degree-days. The development of mature gonads requires 8163 to $8356^{\circ} \mathrm{D}$, approximately a 2 yr period (Lake Thun water group: $678 \mathrm{dph}$ ). Lower water temperatures in the spring water group led to delayed growth of both the gonads and also body size. Interestingly, the impact of lower water tem- 


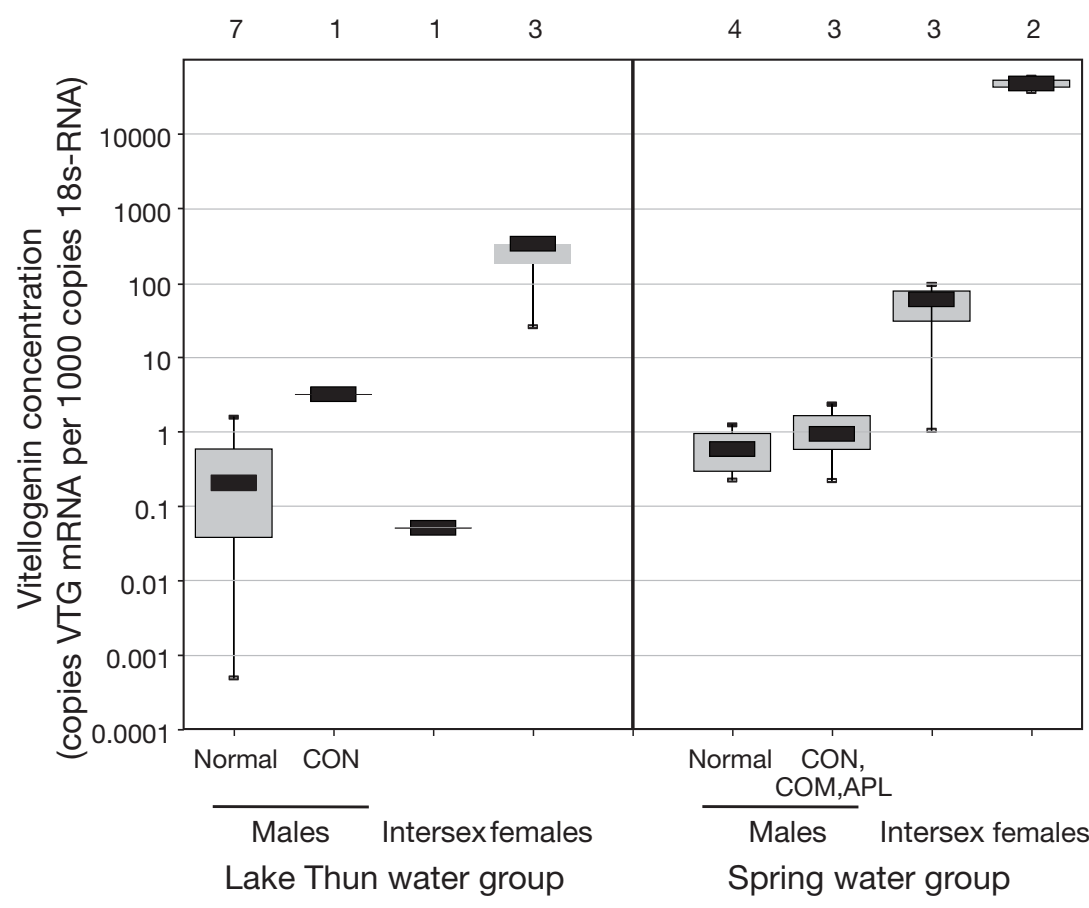

Fig. 6. Coregonus lavaretus. Liver mRNA vitellogenin concentration of males, females and intersex fish from the Lake Thun (age of fish: $850 \mathrm{dph}$ ) and the spring (981 dph) water groups at the final sampling. CON: constricted testes; COM: compartmented testes; APL: aplasia of one testicular strand. Values shown are median (black bar), 25th to 75th percentiles (grey bar) and minimum/maximum. Numbers above the boxplots represent the sample size

peratures was higher on body growth than on gonad growth. Fish from the spring water group generally reached the gonadal development stages not only at older ages, but also with smaller body sizes (more prominent in males than in females; Fig. 2). This means that the different relationships between body length and gonadal developmental stage in the 2 treatment groups was probably the result of the differing rearing temperatures.

Whitefish populations in Lake Thun have previously been reported to show a high prevalence of gonadal deformations (Bernet et al. 2004, Bittner et al. 2009). The present study demonstrates that the same morphological gonad abnormalities seen in wild whitefish from Lake Thun also develop in whitefish reared under artificial conditions, and that gonadal deviations develop concomitantly with gonadal differentiation. Intersex gonads appeared from the very beginning of sexual differentiation of the gonads (i.e. $169 \mathrm{dph}, 2298^{\circ} \mathrm{D}$, $7 \mathrm{~cm}$ fish in the Lake Thun water group). Constrictions and asymmetries developed for the first time in the first $(0+)$ or second $(1+)$ year-of-life, at a body length of 12.5 to $18 \mathrm{~cm}$. Aplasia and compartmentation were recorded in the third (2+) year-of-life at a body length of 16 to $18 \mathrm{~cm}$. The only morphological deviation of wild whitefish that was not observed in the laboratory- reared fish was fusions of gonads to the trunk musculature.

Two findings were striking when comparing the gonadal deviations in experimentally reared fish and fish from the wild population in Lake Thun. First, the frequencies of the macroscopic morphological deviations were significantly lower in experimentally reared fish than in wild whitefish from Lake Thun. Whitefish caught in Lake Thun displayed gonad constrictions in $64 \%$ of mature males and $3 \%$ of mature females during the spawning season and in 1 (females) to $13 \%$ (males) in fish sampled throughout the year (Bittner et al. 2009). Asymmetrical gonads, where the volume of one strand was $\leq 50 \%$ of the other, were found in $14 \%$ of females during the spawning period and in $8 \%$ of females and $4 \%$ of males throughout the year (Bittner et al. in press). Atrophy/aplasia was found in $2 \%$ of mature males and $5 \%$ of mature females during the spawning season and in 1 (males) to $5 \%$ (females) in fish sampled throughout the year. Compartmentation occurred in $25 \%$ of mature males and $4 \%$ of mature females during the spawning season and in 4 (females) to $24 \%$ (males) in fish sampled throughout the year. Fusions of gonads to the peritoneal wall were seen in $4 \%$ of female and 5 to $11 \%$ of male whitefish from Lake Thun. Second, the frequency of microscopic intersex gonads was significantly higher in the experimentally reared fish than in wild Lake Thun whitefish.

The low frequency of macroscopic deviations in gonadal morphology in the laboratory-reared fish may be explained by the absence of an unknown factor in the experimental setup, which is, however, present in the Lake Thun ecosystem and responsible for the induction of the gonadal malformation (i.e. a water contaminant, a food substance). An alternative explanation would be an age-related bias. The prevalence of gonadal deviation in whitefish populations from Lake Thun increases with age, reaching the highest frequencies in 3- to 5-yr-old fish (Bernet et al. 2004). The oldest artificially reared fish in the present study were $2.5 \mathrm{yr}$ old, which may simply not be long enough for the development of significant frequency of gonadal deviations.

In contrast with the macroscopic findings, fish with mosaic intersex gonads were significantly more frequent in the laboratory-reared whitefish than in wild whitefish from Lake Thun. Mosaic intersex in wild whitefish from Lake Thun occurred in $1.1 \%$ of the fish. Another 1\% of Lake Thun coregonids displayed lobu- 
lar intersex (Bernet et al. 2004, Bittner et al. 2009). There are a number of studies reporting an increased frequency of intersex caused by exposure to natural and synthetic environmental pollutants, referred to as endocrine-disrupting chemicals (EDCs) (i.e. Gimeno et al. 1998, Metcalfe et al. 2001, Kidd et al. 2007). However, intersex gonads appear to occur not only in EDCexposed fish populations, as there is evidence, at least in some species of fish (and also amphibians), that a small number of intersex gonads can occur spontaneously as a result of natural variability (Sumpter \& Johnson 2005, Hecker et al. 2006, Grim et al. 2007). Thus, the question of how to interpret the occurrence of intersex fish in the present study arises, and whether it is indicative of EDC exposure or it represents baseline variability. In many studies, both from the field and particularly in the laboratory, an EDC-induced elevation of the frequency of intersex fish in a population was found to be associated with an elevation of VTG levels. One of the best documented examples is the association between VTG levels and intersex manifestation in wild roach in UK rivers (Jobling et al. 1998). For whitefish, we could demonstrate such an association in a laboratory study (Kipfer et al. 2009), where fish were fed a daily ratio of estradiol (E2) until they were 3 yr old. The E2 administration resulted in an immediate dose-dependent increase of VTG mRNA concentrations in males (and the values stayed at those levels over a 3 yr period) and a dose-dependent frequency of intersex fish. In the present study, however, the mRNA concentrations of VTG did not differ significantly between treatments and/or between fish with and without intersex gonads, thereby suggesting no estrogenic impact. Males with morphologically normal gonads from the Lake Thun water group showed mRNA concentrations comparable to normal males of the spring water treatment group (medians of 0.2 and 0.6 copies VTG mRNA $1000^{-1}$ copies 18s-RNA, respectively). Further, VTG mRNA concentrations of males were 3 to 5 orders of magnitude lower than VTG concentration of females, as would be expected for a nonexposure situation. Finally, the mRNA VTG levels of the males from the experimental groups correspond with mRNA concentrations of VTG found in control males reared in tap water (median $=0.1$ copies $1000^{-1}$ copies of 18s-RNA; Kipfer et al. 2009). This tap water control group was part of a long-term (17 $\beta$-E2) exposure experiment and males from that group showed an intersex prevalence of $1 \%$. Male whitefish from the low dose treatment group of the same experiment, fed with a daily intake rate of $0.5 \mu \mathrm{g} \mathrm{E} 2 \mathrm{~kg}^{-1}$ fish, showed not only a significant dose-dependent increase of intersex fish, but also a significant enhancement of median mRNA VTG levels to 5.4 copies $1000^{-1}$ copies of $18 \mathrm{~s}-$ RNA. Therefore, we suppose that the results of the pre- sent study point to a naturally increased level of mosaic intersex gonads during the ontogenetic period of gonad sexual differentiation, rather than indicate an exposure to EDCs in the environment. Our suggestion is based on the following lines of evidence:

- There is no evidence for endocrine disruption. Intersex frequency was increased in both experimental groups, independent of water quality and water temperature. Even in the spring water group, where the presence of endocrine active compounds is very unlikely, the intersex frequency was comparable to that of fish reared in Lake Thun water. An estrogenic effect on the experimental fish via the feed (both groups were fed with commercial dry feed) seems also rather unlikely because there is no evidence for an elevated mRNA VTG level in fish fed with dry food. First, male whitefish of both experimental groups did not show elevated mRNA VTG levels compared with male whitefish reared in spring water and fed exclusively zooplankton from Lake Thun (median $=3.8$ copies VTG mRNA $1000^{-1}$ copies $18 \mathrm{~s}-$ RNA; authors' unpubl. data). Second, mRNA VTG levels of male whitefish from both experimental groups were not increased compared with mRNA VTG levels of wild male whitefish from Lake Thun (sampling at 4 different sites, medians $=0.33$ to 9.68 copies VTG mRNA $1000^{-1}$ copies 18s-RNA; Bernet et al. 2008). Third, Kipfer at al. (2009) have shown that VTG mRNA levels increase in males immediately when fed with estrogen-active compounds, and that the males keep the levels over a 3 yr period as long as the feeding with estrogen-active compounds continues.

- Natural occurrence of mosaic intersex fish at low frequencies-independent of any influence of endocrine disrupting substances-are described in other gonochoristic species, like brown trout Salmo trutta (Ashby 1965, Körner et al. 2005, Bjerregaard et al. 2006), rainbow trout Oncorhynchus mykiss (Schwaiger et al. 2002) and Japanese medaka Oryzias latipes (Grim et al. 2007). In the latter study, a retrospective evaluation of the occurrence of spontaneous intersex in medaka was performed, whereby 54 individual cases of intersex gonads (testicular oocytes or ovarian testicular tissue) were found in the control groups of 15 out of 41 selected toxicological studies. This retrospective study clearly indicates that intersex morphology can occur spontaneously at low prevalence in gonochorist species. We therefore believe that the low frequency of intersex gonads as found in the premature gonads of the gonochoristic whitefish represents a natural, not an induced, variation of gonadal development.

The presence of testicular oocytes as a natural phenomenon during ontogeny, and a decrease in their frequency as the fish matures, agrees with studies on 
gonadal development in African clawed frogs Xenopus laevis exposed to atrazine under outdoor microcosm conditions (Jooste et al. 2005). The authors report a 39 to $59 \%$ prevalence of intersex in recently metamorphosed frogs, independently of whether frogs were exposed to an EDC or not. Ten months after metamorphosis, another subset of juveniles was examined, and both the frequency of frogs with intersex gonads ( 0 to $40 \%$ ) and the number of testicular oocytes per individual were lower. The occurrence of oocytes in testes during early development followed by their disappearance during further development is also referred to as 'rudimentary testicular oocytes' (Hecker et al. 2006).

-We suppose that spontaneous mosaic intersex in whitefish during the ontogenetic period of gonadal differentiation has not been reported so far because the previous studies finished sampling before the onset of intersex conditions. In the studies by Dlugosz \& Demska-Zakes (1992) and Krol et al. (2003) of germ cell differentiation in whitefish, no intersex conditions were described. Gonadal differentiation in these 2 studies was investigated in fish up to an age of 166 and $102 \mathrm{dph}$, respectively. According to our experience, these fish were too young to develop intersex conditions. The first intersex gonads in the present study were found in fish at 169 dph (Lake Thun water group) and $202 \mathrm{dph}$ (spring water group). In contrast, Bogdanova (2002) studied the influence of hybridisation of Coregonus peled with C. nasus on the gonadal development in fish of up to $3 \mathrm{yr}$ in age and mentioned the occurrence of some females with male sex cells. Unfortunately, the prevalence of specimens of this type are not further addressed.

We suggest that mosaic intersex gonads in developing whitefish are a consequence of focal misprogramming in the development of still bivalent germ cells. Among gonochorists, the ultimate fate of the developing gonads is governed by a delicate balance of genetic and environmental factors (Strüssmann \& Nakamura 2002), not seldom resulting in phenotypic sex being different from genotypic sex. The differentiation of PGCs is essentially guided by sex steroids and the activity of steroideogenic enzymes like aromatase (Piferrer 2001). Slight focal variations in the relevant enzyme patterns and/or expression of the steroid receptors may result in an aberrant focal phenotypical sex differentiation of single or few PGCs, resulting in a transient intersex condition during ontogeny, which is, however, not (or only seldom) present in adult fish having terminated their gonadal differentiation process.

In conclusion, in Lake Thun, whitefish primordial gonads were first seen at $65 \mathrm{dph}$ and $491^{\circ} \mathrm{D}$. The development of mature gonads transiently required 8163 to $8356^{\circ} \mathrm{D}$, approximately a $2 \mathrm{yr}$ period. Whitefish fol- lowed a differentiation process typical of gonochorists, having female and male sexes in separate individuals. The onset of the ovarian differentiation clearly preceded that of the testicular differentiation. The results of the present study give evidence for a naturally transiently increased prevalence of mosaic intersex gonads in whitefish during the ontogenetic period of gonadal differentiation, a condition similar to that in frogs named 'rudimentary testicular oocytes' (Hecker et al. 2006). Morphological gonadal deviations seen in wild whitefish from Lake Thun were already evident during gonadal differentiation. Thus, the gonadal deviations are either genetically determined or induced by an endo- or exogenous factor that is active early in the gonadal differentiation process.

Acknowledgements. We thank the Fisheries Inspectorate of Bern for financial support, infrastructure facilities, sampling of whitefish from Lake Thun and especially for their help in fish maintenance and plankton fishing, in particular M. Flück, U. Gutmann, H. Haussener, C. Küng, U. Lehmann and H. Walter. We thank H. U. Kernen for his help in keeping fish of the Lake Thun water group. The fishermen K. Klopfenstein, H. Moser and H. Sieber helped us obtain parental whitefish from Lake Thun. A. Brügger supported us with cutting and reading histological slides. B. Müller is acknowledged for her support during the sampling. This work was funded in part by a grant from the Swiss National Science Foundation (405040106986/1).

\section{LITERATURE CITED}

Ashby KR (1965) The effect of steroid hormones on the development of the reproductive system of Salmo trutta L. when administered at the commencement of spermatogenic activity in the testes. Rev Biol 58:139-169

Atkinson D (1994) Temperature and organism size: A biological law for ectotherms? Adv Ecol Res 25:1-58

Baroiller JF, D'Cotta H (2001) Environment and sex determination in farmed fish. Comp Biochem Physiol C 130: 399-409

> Bernet D, Wahli T, Kueng C, Segner H (2004) Frequent and unexplained gonadal abnormalities in whitefish (central alpine Coregonus sp.) from an alpine oligotrophic lake in Switzerland. Dis Aquat Org 61:137-148

Bernet D, Liedtke A, Bittner D, Eggen RIL and others (2008) Gonadal malformations in whitefish from Lake Thun: defining the case and evaluating the role of EDCs. Chimia 62:383-388

Bittner D, Bernet D, Wahli T, Segner H, Küng C, Largiader CR (2009) How normal is abnormal? Discriminating between deformations and natural variation in gonad morphology of European whitefish Coregonus lavaretus (L). J Fish Biol 74:1594-1614

Bjerregaard LB, Madsen AH, Korsgaard B, Bjerregaard P (2006) Gonad histology and vitellogenin concentrations in brown trout (Salmo trutta) from Danish streams impacted by sewage effluent. Ecotoxicology 15:315-327

Bogdanova VA (2002) Ontogenesis of gonads in Coregonus peled (Gmelin) $\times$ Coregonus nasus (Pallas) hybrids. Arch Hydrobiol Spec Issues Adv Limnol 57:243-252 
Demska-Zakes K, Mamcarz A (1996) Gonadal abnormalities in Coregonus peled Gmel. x Coregonus lavaretus L. hybrids, introduced into natural waters. In: Kirchhofer A, Hefti D (eds) Conservation of endangered freshwater fish in Europe. Birkhäuser, Basel, p 225-232

Dlugosz M, Demska-Zakes K (1992) Sex differentiation in European whitefish (Coregonus lavaretus L.). Pol Arch Hydrobiol 39:633-640

Fitzsimons JD, Cairns VW (2000) Prevalence of a testicular anomaly in lake trout (Salvelinus namaycush) of the Great Lakes basin. J Gt Lakes Res 26:74-81

> Garcia-Reyero N, Raldua D, Quiros L, Llaveria G and others (2004) Use of vitellogenin mRNA as a biomarker for endocrine disruption in feral and cultured fish. Anal Bioanal Chem 378:670-675

> Gimeno S, Komen H, Gerritsen AGM, Bowmer T (1998) Feminisation of young males of the common carp, Cyprinus carpio, exposed to 4-tert-pentylphenol during sexual differentiation. Aquat Toxicol 43:77-92

> Grim KC, Wolfe M, Hawkins T, Johnson R, Wolf J (2007) Intersex in Japanese medaka (Oryzias latipes) used as negative controls in toxicologic bioassays: a review of 54 cases from 41 studies. Environ Toxicol Chem 26: 1636-1643

Hamaguchi S (1992) Sex differentiation of germ cells and their supporting cells in Oryzias latipes. Fish Biol J Medaka 4:11-18

> Hecker M, Murphy MB, Coady KK, Villeneuve DL and others (2006) Terminology of gonadal anomalies in fish and amphibians resulting from chemical exposures. Rev Environ Contam Toxicol 187:103-131

> Jobling S, Nolan M, Tyler C, Brighty G, Sumpter JP (1998) Widespread sexual disruption in wild fish. Environ Sci Technol 32:2498-2506

Jooste AM, Du Preez LH, Carr JA, Giesy JP and others (2005) Gonadal development of larval male Xenopus laevis exposed to atrazine in outdoor microcosms. Environ Sci Technol 39:5255-5261

Kidd KA, Blanchfield PJ, Mills KH, Palace VP, Evans RE, Lazorchak JM, Flick RW (2007) Collapse of a fish population after exposure to a synthetic estrogen. Proc Natl Acad Sci USA 104:8897-8901

Kinnison MT, Unwin MJ, Jara F (2000) Macroscopic intersexuality in salmonid fish. N Z J Mar Freshw Res 34:125-134

Kipfer S, Segner H, Wenger M, Wahli T, Bernet D (2009) Long-term estrogen exposure of whitefish Coregonus lavaretus induces intersex but not Lake Thun-typical gonad malformations. Dis Aquat Org 84:43-56

Körner O, Vermeissen ELM, Burkhardt-Holm P (2005) Intersex in feral brown trout from Swiss midland rivers. J Fish Biol 67:1734-1740

Krol J, Demska-Zakes K, Hliwa P, Korzeniowska G (2003) The influence of temperature on the sex differentiation process in peled Coregonus peled (Gmel.). Arch Pol Fish 11:23-31

Lynch M, Walsh B (1998) Genetics and analysis of quantitative traits. Sinauer Associates, Sunderland, MA

> Maack G, Segner H (2003) Morphological development of the gonads in zebrafish. J Fish Biol 62:895-906

Metcalfe CD, Metcalfe TL, Kiparissis Y, Koenig BG and others (2001) Estrogenic potency of chemicals detected in sewage treatment plant effluents as determined by in vivo assays

Editorial responsibility: Asbjørn Vøllestad, Oslo, Norway with Japanese medaka (Oryzias latipes). Environ Toxicol Chem 20:297-308

Mikaelian I, Martineau D, De Lafontaine Y, Harshbarger JC, Lee LLJ (2002) Health of lake whitefish (Coregonus clupeaformis) with elevated tissue levels of environmental contaminations. Environ Toxicol Chem 21:532-541

Nakamura M, Kobayashi T, Chang XT, Nagahama Y (1998) Gonadal sex differentiation in teleost fish. J Exp Zool 281: 362-372

Neuheimer AB, Taggart CT (2007) The growing degree-day and fish size-at-age: the overlooked metric. Can J Fish Aquat Sci 64:375-385

> Nolan M, Jobling S, Brighty G, Sumpter JP, Tyler CR (2001) A histological description of intersexuality in the roach. J Fish Biol 58:160-176

Patino R, Redding J (2000) Microscopical functional anatomy: reproductive systems. In: Ostrander GK (ed) Handbook of experimental animals. The laboratory fish. Academic Press, London, p 489-500

Pfaffl MW (2001) A new mathematical model for relative quantification in real-time RT-PCR. Nucleic Acids Res 29:e45

> Piferrer F (2001) Endocrine sex control strategies for the feminization of teleost fish. Aquaculture 197:229-281

Ruby SM, Cairns V (1983) Implications of testicular constrictions on spermatogenesis in Lake Ontario lake trout, Salvelinus namaycush. J Fish Biol 23:385-395

Schwaiger J, Mallow U, Ferling H, Knoerr S, Braunbeck T, Kalbfus W, Negele RD (2002) How estrogenic is nonylphenol? A transgenerational study using rainbow trout (Oncorhynchus mykiss) as a test organism. Aquat Toxicol 59:177-189

Simpson MG, Parry M, Kleinkauf A, Swarbreck D, Walker P, Leah RT (2000) Pathology of the liver, kidney and gonad of flounder (Platichthys flesus) from a UK estuary impacted by endocrine disrupting chemicals. Mar Environ Res 50: 283-287

> Strüssmann CA, Nakamura M (2002) Morphology, endo crinology, and environmental modulation of gonadal sex differentiation in teleost fish. Fish Physiol Biochem 26:13-29

Strüssmann CA, Karube M, Miranda LA, Patino R, Somoza GM, Uchida D, Yamashita M (2002) Methods of sex control in fishes and an overview of novel hypotheses concerning the mechanisms of sex differentiation. In: Pandian TJ, Strüssmann CA, Marian MP (eds) Fish genetics and aquaculture biotechnology. Oxford \& IBH Publishing, New Delhi, and Science Publishers, Enfield, NH

Sumpter JP, Johnson AC (2005) Lessons from the endocrine disruption and their application to other issues concerning trace organics in the aquatic environment. Environ Sci Technol 39:4321-4332

van Aerle R, Runnalls TJ, Tyler CR (2004) Ontogeny of gonadal sex development relative to growth in fathead minnow. J Fish Biol 64:355-369

> van den Hurk R, Slof GA (1981) A morphological and experimental study of gonadal sex differentiation in the rainbow trout, Salmo gairdneri. Cell Tissue Res 218:487-497

Wiklund T, Lounasheimo L, Lom J, Bylund G (1996) Gonadal impairment in roach Rutilus rutilus from Finnish coastal areas of the northern Baltic Sea. Dis Aquat Org 26:163-171

Submitted: November 19, 2008; Accepted: April 7, 2009

Proofs received from author(s): May 19, 2009 